\title{
QUESTIONNAIRE ON THE MIDWIVES' KNOWLEDGE ABOUT ORAL EMERGENCY CONTRACEPTION
}

\author{
Dinka Pavičić Baldani ${ }^{1}$, Lana Škrgatić ${ }^{1}$, Marina Šprem Goldštajn ${ }^{1}$, \\ Trpimir Goluža ${ }^{2}$ Ivana Flisar ${ }^{3}$ and Sandra Pagon ${ }^{3}$
${ }^{1}$ Department of Obstetrics and Gynecology, Division of Reproductive Endocrinology and Reproductive Medicine, Zagreb University Hospital Centre, University of Zagreb, School of Medicine, Zagreb, Croatia; ${ }^{2}$ Department of Obstetrics and Gynecology, Division of Perinatal Medicine, Zagreb University Hospital Centre, University of Zagreb, School of Medicine, Zagreb, Croatia; ${ }^{3}$ medical student, University of Zagreb, School of Medicine, Zagreb, Croatia

\begin{abstract}
SUMMARY - The aim of the study was to assess the level of knowledge of midwives working in different clinical settings about oral emergency contraception. The study included 225 midwives; during the period from December 2015 to February 2016, they completed a 16-item web-based survey using the SurveyMonkey software available on the Croatian Midwives Chamber site. In total 277 participants started to fill out the survey and 225 participants responded to all 16 questions. Demographic, educational and professional characteristics of the participants in this survey are provided. Distribution of participant responses to questions regarding basic reproductive endocrinology, unplanned pregnancies and emergency contraception clearly revealed important gaps in the group knowledge. There was evident gap in the knowledge about emergency contraception in the study group of Croatian midwives. Having in mind the study group grounds in gynecology and obstetrics, and their public health relevance, targeted educational activities both during midwife formal education and on-job are required to improve the group knowledge about emergency contraception. National guidelines on oral emergency contraception are an at hand learning tool and the most appropriate local source of information on emergency contraception. Various initiatives should be considered for this document to become an integral part of formal midwife education and regular part of their on-job trainings.
\end{abstract}

Key words: Pregnancy, unplanned; Contraception, postcoital; Midwifery - education; Public health; Surveys and questionnaires; Health knowledge, attitudes, practice

\section{Introduction}

Despite the availability of many reliable methods of contraception, the incidence of unintended pregnancies is still unacceptably high. Oral emergency contraception is a unique method of preventing unin-

Correspondence to: Lana Škrgatic, $M D, P h D$, Department of Obstetrics and Gynecology, Division of Reproductive Endocrinology and Reproductive Medicine, Zagreb University Hospital Centre, University of Zagreb, School of Medicine, Petrova 13, HR-10000

Zagreb, Croatia

E-mail: lana.skrgatic@mef.hr

Received December 21, 2016, accepted January 18, 2017 tended pregnancy, since it is applied after unprotected sexual intercourse has occurred or after failure of the currently used method of contraception. Although there is clear evidence that this contraceptive method prevents the risk of pregnancy at the individual level, the impact on reducing the prevalence of unintended pregnancies and abortion rates at the population level is still unknown. In the past, authors have systematically evaluated the potential reasons and concluded that this fact seems to be related to the insufficient use of these methods, due to the barriers to access but also due to the lack of knowledge not only in general population but also among healthcare providers ${ }^{1}$. 
In the context of our previous research, the aim of the current study was therefore to explore gaps in the knowledge of midwives working in different counties in Croatia in order to plan their future education regarding emergency contraception and to improve counseling and removing barriers to its use.

\section{Materials and Methods}

\section{Study design}

A cross-sectional web-based survey was created using the SurveyMonkey online survey software (SurveyMonkey, Inc., USA). Participants were invited to participate via link placed on web pages of the Croatian Chamber of Midwives (www.komora-primalja. hr). The survey was launched on December 16, 2015 and closed on February 16, 2016. The questionnaire used in the survey is provided in the Appendix.

\section{Study population}

Target population were midwives aged 18-60 years working in different Croatian counties. It was a survey aimed to test gaps in the knowledge of targeted population on oral emergency contraception in order to plan future education. As such, it did not require ethics committee approval but was carried out in accordance with the standard ethics principles for this type of research. Participation was voluntary and fully anonymous.

\section{Interventions}

The questionnaire included 16 questions that addressed demographic characteristics of the participants, their knowledge about the risk of pregnancy, about the mechanism of action of oral emergency contraception, and timing of oral emergency contraception. Descriptive statistics was used to describe the data obtained. Results were expressed as absolute numbers and percentages.

\section{Results}

In total 277 participants started to fill out the survey and 225 of them provided answers to all 16 questions. Demographic characteristics of the survey participants are shown in Table 1 . The majority of respondents were aged $\geq 25$ years $(94.22 \%)$ and $35.03 \%$ were
Table 1. Characteristics of study participants

\begin{tabular}{|l|l|}
\hline Characteristic & $\mathrm{n}(\%)$ \\
\hline Age group (years): & $16(5.78)$ \\
18-24 & $98(35.38)$ \\
$25-34$ & $66(23.83)$ \\
$35-44$ & $97(35.02)$ \\
$45-60$ & \\
\hline Educational level: & $194(70.04)$ \\
High school & $57(20.58)$ \\
Baccalaurean & $17(6.14)$ \\
Master degree & $4(1.44)$ \\
Postdoctoral degree & $5(1.81)$ \\
Other & \\
\hline Length of employment & \\
as midwife (years): & $71(25.63)$ \\
0-5 & $42(15.16)$ \\
6-10 & $85(30.69)$ \\
11-25 & $64(23.10)$ \\
26-35 & $15(5.42)$ \\
$>36$ & \\
\hline County of employment: & $116(41.88)$ \\
City of Zagreb & $27(9.75)$ \\
Primorje-Gorski Kotar & $21(7.58)$ \\
Split-Dalmatia & $13(4.69)$ \\
Sisak-Moslavina & $12(4.33)$ \\
Krapina-Zagorje & $11(3.97)$ \\
Međimurje & $10(3.61)$ \\
Brod-Posavina & $10(3.61)$ \\
Karlovac & $10(3.61)$ \\
Vukovar-Srijem & $10(3.61)$ \\
Zadar & $6(2.17)$ \\
Osijek-Baranja & $5(1.81)$ \\
Bjelovar-Bilogora & $5(1.81)$ \\
Dubrovnik-Neretva & $5(1.81)$ \\
Koprivnica-Križevci & $5(1.81)$ \\
Šibenik-Knin & $5(1.81)$ \\
Varaždin & $3(1.08)$ \\
Požega-Slavonija & $2(0.72)$ \\
Istria & $2(0.72)$ \\
Lika-Senj & $1(0.36)$ \\
Virovitica-Podravina & \\
\hline & \\
\hline
\end{tabular}

aged $>44$ years. The majority (70.04\%) of participants shared an equal level of education (high school). Less than 10 years of experience as midwife was recorded in $40.79 \%$ of participants, while almost one-third had over 25 years of nursing experience (28.52\%). The participants having responded to the online questionnaire were predominantly from the City of Zagreb (41.88\%), 
Table 2. Participants' knowledge about risks of unintended pregnancy

\begin{tabular}{|l|l|}
\hline Item & $\mathrm{n}(\%)^{1}$ \\
\hline $\begin{array}{l}\text { Forty-four percent of pregnancies } \\
\text { are unplanned }\end{array}$ & \\
Correct & $182(73.98)$ \\
Incorrect & $64(26.02)$ \\
\hline $\begin{array}{l}\text { Around 2/3 of unintended } \\
\text { pregnancies end with abortion }\end{array}$ & \\
Correct & $116(47.15)$ \\
Incorrect & $130(52.85)$ \\
\hline $\begin{array}{l}\text { Sperm survival in female } \\
\text { reproductive organs is 5 days }\end{array}$ & \\
Correct & $113(45.93)$ \\
Incorrect & $133(54.07)$ \\
\hline $\begin{array}{l}\text { The egg can be fertilized for up to } \\
24 \text { hours after ovulation }\end{array}$ & \\
Correct & $153(62.20)$ \\
Incorrect & $93(37.80)$ \\
\hline $\begin{array}{l}\text { Ovulation is variable even in women } \\
\text { with regular menstrual cycles }\end{array}$ & \\
Correct & $212(86.18)$ \\
Incorrect & $34(13.82)$ \\
\hline $\begin{array}{l}\text { Safe' days do not exist - risk } \\
\text { of pregnancy is present each day } \\
\text { of the menstrual cycle } \\
\text { Correct } \\
\text { Incorrect }\end{array}$ & $103(41.87)$ \\
\hline
\end{tabular}

${ }^{1} \mathrm{~N}=246$

followed by Primorje-Gorski Kotar County (9.75\%) and Split-Dalmatia County (7.58\%). The remaining participants were from all other Croatian counties.

Answers to the questions regarding the risk of unplanned pregnancy are shown in Table 2. These questions were answered by 246 participants. The majority of participants knew that $44 \%$ of pregnancies were unplanned (73.98\%) but more than half (52.85\%) stated wrongly that they did not agree with the statement that $2 / 3$ of unplanned pregnancies ended with abortion. When asked whether sperm survives 5 days in female reproductive tract, little less than half (45.93\%) of the responders answered correctly, while the majority were aware that the egg could be fertilized for up to 24 hours after ovulation. A remarkable proportion (86.18\%) of participants responded correctly that ovulation time varied even in women with regular menstrual cycles, so it is surprising that less than half
Table 3. Participants' knowledge concerning emergency contraception

\begin{tabular}{|l|l|}
\hline Item & $\mathrm{n}(\%)$ \\
\hline $\begin{array}{l}\text { Oral emergency contraception } \\
\text { causes abortion }\end{array}$ & \\
Correct & $97(42.92)$ \\
Incorrect & $129(57.08)$ \\
\hline $\begin{array}{l}\text { Oral emergency contraception } \\
\text { has teratogenic effects }\end{array}$ & \\
Correct & $67(29.65)$ \\
Incorrect & $159(70.35)$ \\
\hline $\begin{array}{l}\text { Oral emergency contraception } \\
\text { negatively affects future fertility }\end{array}$ & \\
Correct & $21(9.29)$ \\
Incorrect & $205(90.71)$ \\
\hline Emergency contraception promotes & \\
irresponsible sexual behavior & $126(55.75)$ \\
Correct & $100(44.25)$ \\
Incorrect & \\
\hline $\begin{array}{l}\text { Oral emergency contraception } \\
\text { causes hormonal imbalance }\end{array}$ & $122(53.98)$ \\
Correct & $104(46.02)$ \\
Incorrect & \\
\hline $\begin{array}{l}\text { Oral emergency contraception } \\
\text { is provided until 14th menstrual } \\
\text { cycle day }\end{array}$ & \\
Correct & \\
Incorrect & \\
\hline
\end{tabular}

(41.87\%) believed that the statement on the risk of pregnancy to be present each day of the menstrual cycle was not correct.

The respondents' knowledge concerning emergency contraception is shown in Table 3. More than half (57.8\%) responded that the statement on emergency contraception to act as an abortificient was not true, and the majority of them were aware that emergency contraception had no teratogenic effects (70.35\%). Most respondents (90.71\%) were aware that oral emergency contraception had no negative effect on future fertility. More than half (55.75\%) of the participants stated that emergency contraception promoted irresponsible sexual behavior, as well as hormonal imbalance (53.98\%). Furthermore, 187 (82.74\%) participants considered correctly that emergency contraception was not only provided until the $14^{\text {th }}$ menstrual cycle day but throughout the menstrual cycle due to unpredictability of ovulation time. 


\section{Discussion}

This cross-sectional web-based online survey was conducted to explore the level of knowledge about oral emergency contraception among midwives in Croatia. Midwives as healthcare providers are in first contact with our female patients. That is why they are in a key position to provide information on oral emergency contraception. It is important that they are equipped with correct information they will pass to their patients in order to overcome the misconceptions, which still exist regarding emergency contraception. Study respondents represented all Croatian counties. Around $40 \%$ of responses were recorded from Zagreb, but only one-fourth of the Croatian population live in Zagreb. Around one-third of our respondents were aged over 45 , which is a positive surprise considering that it was an online survey with the link placed on the Croatian Chamber of Midwives web pages.

The results of this survey pointed to a gap in the knowledge about the key facts regarding the risk of unintended pregnancy. More than half of our participants were not aware that sperm could survive for up to $120 \mathrm{~h}$ in female reproductive tract, even though they responded correctly to the questions that 'safe' days do not exist and that the risk of pregnancy is present each day of the menstrual cycle. Unprotected intercourse can result in pregnancy in a very limited time frame within the menstrual cycle ${ }^{2}$. Since sperm can survive for up to five days (120 hours) and oocyte is viable for 12-14 hours following ovulation, the time frame when fertilization may proceed ('fertile window') is around 6 days. 'Fertile window' begins 5 days prior to $\mathrm{LH}$ peak (LH-5) and ends one day following $\mathrm{LH}$ peak $(\mathrm{LH}+1)^{2}$. Population studies have demonstrated that almost $70 \%$ of women experience 'fertile days' outside the expected 'fertile window', meaning that around $88 \%$ of women do not ovulate on cycle day $14^{3}$. Our respondents were greatly aware that ovulation was variable in each woman but still around $40 \%$ were unaware of the fact that 'safe' days did not exist within the cycle.

Around one-third of our participants still considered that emergency contraception was abortive and had a potential teratogenic effect on pregnancy. These findings are in line with the findings of some previ- ously published studies that tested the knowledge on emergency contraception among healthcare provid$\mathrm{ers}^{4,5}$. Emergency contraceptive pills prevent pregnancy primarily by delaying or inhibiting ovulation and inhibiting fertilization. The best available evidence indicates that oral emergency contraception prevents pregnancy by the mechanisms that do not interfere with post-fertilization events ${ }^{6,7}$, concluding that emergency contraception pills do not cause abortion. This is clearly stated in all relevant global guidelines and statements $^{8-12}$. It is accepted, however, that infants are not at a higher risk of anomalies after unsuccessful use of oral emergency contraception ${ }^{13-15}$.

Surprisingly, more than half of our responders stated that emergency contraception promoted irresponsible sexual behavior. Results from fifteen different population studies clearly demonstrate that accessibility of oral emergency contraception does not increase the incidence of undesirable sexual and contraceptive behavior ${ }^{16}$.

A vast majority of our study participants were aware that oral emergency contraception did not negatively affect future fertility, which is in line with reports from the study that tested the use and attitudes towards emergency contraception in five different European countries ${ }^{17}$.

This short web-survey, designed primarily to explore gaps in the knowledge of midwives working in different counties in Croatia, showed that some misconceptions still existed. Having in mind the study group's grounds in gynecology and obstetrics, and their public health relevance, targeted educational activities both during midwife formal education ${ }^{18}$ and on job $^{19}$ are required to improve the group's knowledge on emergency contraception. National guidelines on oral emergency contraception issued by the Society of Gynecologic Endocrinology and Human Reproduction (HDGEHR), Croatian Society of Gynecology (HDGO) and Gynecology Primary Practice Section of the Croatian Medical Association ${ }^{20}$ are an available learning tool and the most appropriate local source of information on emergency contraception. Various initiatives should be considered for this document to become an integral part of formal midwife education and regular part of their on-job trainings. 


\section{Appendix}

\section{QUESTIONNAIRE ON KNOWLEDGE ABOUT ORAL EMERGENCY CONTRACEPTION}

Q1: Your age (choose one answer):

- 18-24 years

- 25-34 years

- $35-44$ years

- 45-60 years

Q2: Your level of education (choose one answer):

- High school

- Baccalaurean

- Master degree

- Postdoctoral degree

- Other

Q3: Length of employment as midwife (choose one answer):

- $0-5$ years

- 6-10 years

- 11-25 years

- 26-35 years

- 36 years

Q4: County of employment (choose one answer):

- Krapina-Zagorje

- Sisak-Moslavina

- Karlovac

- Varaždin

- Koprivnica-Križevci

- Bjelovar-Bilogora

- Primorje-Gorski Kotar

- Lika-Senj

- Virovitica-Podravina

- Požega-Slavonija

- Brod-Posavina

- Zadar

- Osijek-Baranja

- Šibenik-Knin

- Vukovar-Srijem

- Split-Dalmatia

- Istria

- Dubrovnik-Neretva

- Međimurje

- City of Zagreb

Q5: Forty-four percent of pregnancies are unplanned

- Correct

- Incorrect

Q6: Around 2/3 of unintended pregnancies end with abortion

- Correct

- Incorrect
Q7: Sperm survival in female reproductive organs is 5 days

- Correct

- Incorrect

Q8: The egg can be fertilized for up to 24 hours after ovulation

- Correct

- Incorrect

Q9: Ovulation is variable even in women with regular menstrual cycles

- Correct

- Incorrect

Q10: «Safe days do not exist - risk of pregnancy is present each day of the menstrual cycle

- Correct

- Incorrect

Q11: Oral emergency contraception causes abortion

- Correct

- Incorrect

Q12: Oral emergency contraception has teratogenic effects

- Correct

- Incorrect

Q13: Oral emergency contraception negatively affects future fertility

- Correct

- Incorrect

Q14: Emergency contraception promotes irresponsible sexual behavior

- Correct

- Incorrect

Q15: Oral emergency contraception causes hormonal imbalance

- Correct

- Incorrect

Q16: Oral emergency contraception is provided until $14^{\text {th }}$ menstrual cycle day

- Correct

- Incorrect 


\section{References}

1. Goldštajn MS, Baldani DP, Vrčić H, Orešković S. Emergency contraception: can we benefit from lessons learned? Coll Antropol. 2012;36(1):345-9.

2. Wilcox AJ, Weinberg CR, Baird DD. Timing of sexual intercourse in relation to ovulation. Effects on the probability of conception, survival of the pregnancy, and sex of the baby. $\mathrm{N}$ Engl J Med. 1995;333:1517-21. doi:10.1056/NEJM199512073332301

3. Wilcox AJ, Dunson D, Baird DD. The timing of the "fertile window" in the menstrual cycle: day specific estimates from a prospective study. BMJ. 2000;321:1259-62.

4. Lee CJ, Ahonen K, Apling M, Bork C. Emergency contraception knowledge among nurse practitioner students. J Am Acad Nurse Pract. 2012;24(10):604-11. doi: 10.1111/j.2040-1124.2010.00046.x

5. Aksu H1, Kucuk M, Karaoz B, Oğurlu N. Knowledge and attitudes of health care providers working in primary health care units concerning emergency contraception. Gynecol Obstet Invest. 2010;70(3):179-85. doi:10.1159/000316267

6. Berger C, Boggavarapu NR, Menezes J, et al. Effects of ulipristal acetate on human embryo attachment and endometrial cell gene expression in an in vitro co-culture system. Hum Reprod. 2015;30:800-11. doi:10.1093/humrep/dev030

7. Lalitkumar PG, Lalitkumar S, Meng CX, et al. Mifepristone, but not levonorgestrel, inhibits human blastocyst attachment to an in vitro endometrial three-dimensional cell culture model. Hum Reprod. 2007;22:3031-7. doi:10.1093/humrep/dem297

8. Committee on HealthCare for Underserved Women. ACOG Committee Opinion Number 542: Access to emergency contraception. Obstet Gynecol. 2012;120:1250-3. doi: http://10.1097/AOG.0b013e318277c960

9. Societaà Italiana della Contraccezione. Position paper sulla contraccezione d)emergenza orale 2013. http://www.sicontraccezione.it/pubblicazioni/pdf/ SICSMICpositionpaper20aprile2013.pdf. Last accessed: 01.12.2016. (in Italian)
10. Rabe T, Albring C, Ahrendt HJ, et al. Notfallkontrazeption - ein Update. Gynäkol Endokrinol. 2013;11:197-202. (in German)

11. Glasier A, Gemzell-Danielsson K, Bouchard P, et al. ISGE statement on oral emergency contraception. Gynecol Endocrinol. 2014;30:681-2.

12. Faculty of Sexual and Reproductive Healthcare of the Royal College of Obstetricians and Gynecologists. Emergency contraception - CEU Guidelines 2011. http://www.fsrh.org/.../ CEUguidanceEmergency-Contraception11.pdf. Last accessed: 01.12.2016.

13. Levy DP, Jager M, Kapp N, et al. Ulipristal acetate for emergency contraception: postmarketing experience after use by more than 1 million women. Contraception. 2014;89:431-3. doi: 10.1016/j.contraception.2014.01.003

14. Grimes DA, Raymond EG, Scott Jones B. Emergency contraception over-the-counter: the medical and legal imperatives. Obstet Gynecol. 2001;98:151-5.

15. Grimes DA, Raymond EG. Emergency contraception. Ann Intern Med. 2002;137:180-9.

16. Trussel J, Bimla Schwarz MD. Emergency contraception. In: Trussel J, Nelson AL, Cates W, Kowal D, Policar MM, Eds. Contraceptive Technology 2011. p. 113-49.

17. Nappi RE1, Lobo Abascal P, Mansour D, Rabe T, Shojai R; Emergency Contraception Study Group. Use of and attitudes towards emergency contraception: a survey of women in five European countries. Eur J Contracept Reprod Health Care. 2014;19(2):93-101. doi:10.3109/13625187.2013.865164

18. Čukljek S, Jureša V, Bile CG, Režek B. Changes in nursing students> attitudes towards nursing during undergraduate study. Acta Clin Croat. 2017;56(1):36-43. doi: 10.20471/acc.2017.56.01.06

19. Benceković Ž, Benko I, Režek B, Grbas-Bile C. The role and promotion of nursing. Acta Clin Croat. 2016;55(2):271-8.

20. Oralna hitna kontracepcija. S2k stručne smjernice za primjenu oralne hitne kontracepcije. FotoSoft Zagreb 2015. hdhr.org/ izdanja/ORALNA-HITNA-KONTRACEPCIJA.pdf. Last accessed: 01.12.2016. (in Croatian) 
Sažetak

\title{
UPITNIK O ZNANJU PRIMALJA O HITNOJ ORALNOJ KONTRACEPCIJI
}

\author{
D. Pavičić Baldani, L. Škrgatić, M. Šprem Goldštajn, T. Goluža, I. Flisar i S. Pagon
}

Cilj istraživanja bio je procijeniti znanje iz područja hitne kontracepcije među primaljama u Hrvatskoj. Članice Hrvatske komore primalja ispunjavale su upitnik Survey Monkey od 16 pitanja na temu neplanirane trudnoće i hitne kontracepcije putem stranica Komore u razdoblju od prosinca 2015. do veljače 2016. godine. Ukupno 277 ispitanica pristupilo je upitniku. $\mathrm{Na}$ svih 16 pitanja odgovorilo je 225 ispitanica. Utvrđene su demografske, obrazovne i radne karakteristike ove skupine. Utvrđena je distribucija odgovora ispitanica na pitanja kojima se ispitivalo znanje iz područja fiziologije reprodukcije, neplanirane trudnoće i hitne kontracepcije. Ispitivanje je pokazalo manjkavosti u znanju ispitivane skupine iz područja fiziologije reprodukcije, neplanirane trudnoće i hitne kontracepcije. Imajući na umu snažnu povezanost primalja s ginekološkom strukom te prepoznajući njihov javnozdravstveni utjecaj i potencijal za izobrazbu opće populacije žena potrebno je uspostaviti ciljane obrazovne aktivnosti kako tijekom formalnog obrazovanja primalja tako i u obliku trajnog obrazovanja uz rad kako bi se unaprijedilo znanje u području hitne kontracepcije. Nacionalne smjernice za oralnu hitnu kontracepciju su lokalno najznačajniji i izravno dostupan izvor relevantnih informacija iz ovoga područja pa je potrebno pokrenuti inicijativu kako bi ovaj važan stručni dokument postao integralni dio formalnog obrazovanja i trajnog usavršavanja primalja.

Ključne riječi: Trudnoća, neplanirana; Kontracepcija, postkoitalna; Primaljstvo - izobrazba; Javno zdravstvo; Ankete i upitnici; Obaviještenost pacijenata, stavovi, praksa 